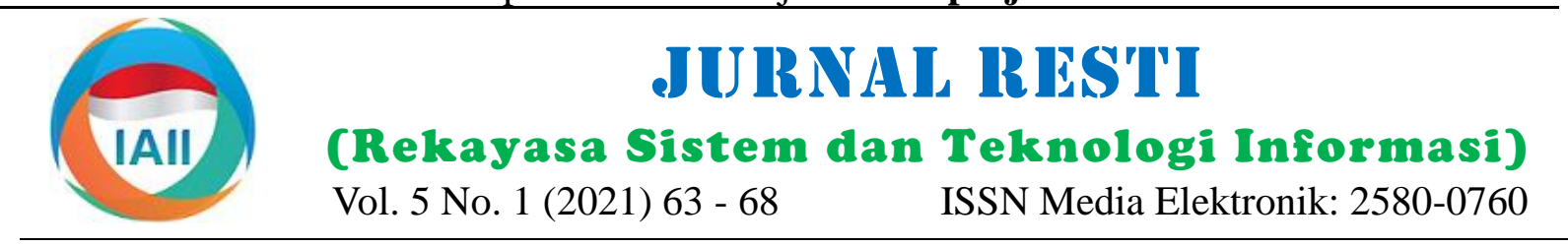

\title{
Temu Kembali Informasi pada Soal Ujian dengan Rencana Pembelajaran Menggunakan Vector Space Model
}

\author{
Amalia Beladinna Arifa ${ }^{1}$, Gita Fadila Fitriana ${ }^{2}$, Ananda Rifkiy Hasan ${ }^{3}$ \\ ${ }^{1}$ Prodi S1 Teknik Informatika, Fakultas Informatika, Institut Teknologi Telkom Purwokerto \\ ${ }^{2,3}$ Prodi S1 Rekayasa Perangkat Lunak, Fakultas Informatika, Institut Teknologi Telkom Purwokerto \\ 19amalia@ittelkom-pwt.ac.id, ${ }^{2}$ gita@ittelkom-pwt.ac.id, ${ }^{3} 18104004 @$ ittelkom-pwt.ac.id
}

\begin{abstract}
One way to find out the quality of exam questions is by looking at the rules for writing exam questions made based on the subject or discussion contained in the learning plan document. Therefore, the exam questions that are arranged must be adjusted to the main material in each subject learning achievement. This study discusses the implementation of the concept in information retrieval systems using the Vector Space Model method. The Vector Space Model method has an advantage in query matching because it is able to match only part of the query with existing documents. In addition, the Vector Space Model method is also easy to adapt by adjusting parameters, including weighting parameters. The weighting calculation for each term that appears in the document uses TF$I D F$. The purpose of this study is to design an information retrieval system to find the suitability of the exam question query with the subject contained in the learning plan document. The suitability is sorted based on the similarity value of the calculation results, from the largest value to the smallest value in the form of a percentage.
\end{abstract}

Keywords: information retrieval, search engine, exam questions, learning plan document, vector space model.

\begin{abstract}
Abstrak
Salah satu cara untuk mengetahui kualitas soal ujian yaitu dengan melihat kaidah penulisan soal ujian yang dibuat berdasarkan materi pokok atau bahasan yang terdapat di dokumen rencana pembelajaran. Soal ujian yang disusun harus disesuaikan dengan materi pokok pada setiap capaian pembelajaran mata kuliah. Penelitian ini membahas mengenai penerapan konsep dalam sistem temu kembali informasi menggunakan pendekatan metode Vector Space Model (VSM). Metode Vector Space Model memiliki kelebihan dalam pencocokan query karena mampu mencocokkan hanya sebagian query saja dengan dokumen yang ada. Selain itu metode Vector Space Model juga mudah beradaptasi melalui penyesuaian parameter, termasuk parameter pembobotannya. Perhitungan pembobotan tiap kata (term) yang muncul pada dokumen menggunakan TF-IDF. Implementasi sistem temu kembali informasi (retrieval of information) sebagai media pencari kecocokan dan kesesuaian antara query soal ujian dengan materi pokok dokumen Rencana Pembelajaran (RPS), hal tersebut merupakan tujuan dari penelitian ini. Kesesuaian tersebut diurutkan berdasarkan nilai kemiripan hasil perhitungannya, dari nilai terbesar ke nilai terkecil dalam bentuk persentase.
\end{abstract}

Kata kunci: temu kembali informasi, Rencana Pembelajaran Semester, vector space model.

\section{Pendahuluan}

Pendidikan di setiap jenjang diselenggarakan berdasarkan kurikulum yang ditetapkan dalam standar isi pendidikan nasional. Peraturan kememenristekdikti No. 44 Tahun 2015 tentang Standar Nasional Pendidikan Tinggi, kurikulum dimaknai sebagai
"Seperangkat rencana dan pengaturan mengenai capaian pembelajaran lulusan, bahan kajian, proses dan penilaian yang digunakan sebagai pedoman penyelenggaraan program studi" [1]. Kurikulum pendidikan tinggi kemudian dikembangkan lagi menjadi Rencana Pembelajaran Semester (RPS). RPS 
merupakan gambaran prosedur pembelajaran yang berbahasa Indonesia menggunakan Vector Space dirancang untuk memenuhi capaian pembelajaran Retrieval Model [8]. Hasil dari penelitian tersebut lulusan yang dibebankan di suatu mata kuliah. Dosen menunjukkan bahwa sistem temu kembali informasi diharuskan untuk menyusun dokumen RPS sebelum menggunakan metode Vector Space Retrieval Model memulai proses pembelajaran untuk setiap mata kuliah dapat memberikan solusi pada mesin pencarian berupa yang diampunya. Isi dari dokumen tersebut setidaknya informasi kecocokan teks dalam database menggunakan terdiri dari peta capaian pembelajaran mata kuliah, kata kunci tertentu. Di bidang pendidikan, metode deskripsi mata kuliah, tujuan perkuliahan, capaian Vector Space Model juga diimplementasikan pada pembelajaran lulusan yang dibebankan di mata kuliah, aplikasi penentuan dosen penguji skripsi [9]. Hasil capaian pembelajaran mata kuliah, materi pokok, penelitian diperoleh akurasi sebesar 93,22\%, dimana strategi pembelajaran, evaluasi/penilaian pembelajaran, sistem dapat memberikan rekomendasi sebanyak tiga daftar rujukan, serta jadwal perkuliahan.

Proses pembelajaran terdapat evaluasi yang merupakan faktor penting. Dikarenakan posisi evaluasi setara dengan kesesuaian tujuan pembelajaran [2]. Salah satu Metode Vector Space Model, sebuah dokumen bagian dari kegiatan evaluasi adalah pembuatan dipandang sebagai sebuah vektor yang memiliki jarak instrumen penilaian yang digunakan untuk mengukur (magnitude) dan arah (direction) [10]. Metode Vector kemampuan dan hasil belajar mahasiswa sesuai dengan Space Model dapat dihasilkan tingkat kemiripan antar capaian pembelajaran mata kuliah. Salah satu bentuk kata, frase dan dokumen dengan cara pembobotan kata instrumen penilaian adalah soal ujian atau tes. Soal ujian (term). Metode Vector Space Model memiliki kelebihan sebagai instrumen penilaian adalah sekumpulan dalam pencocokan query karena mampu mencocokkan pertanyaan yang diberikan kepada siswa untuk hanya sebagian query dengan dokumen yang ada. Selain mendapatkan jawaban dari siswa dalam bentuk lisan, itu metode Vector Space Model juga mudah beradaptasi tulisan atau perbuatan [3]. Soal ujian dalam bentuk melalui penyesuaian parameter, termasuk parameter tulisan sering digunakan untuk mengukur kemampuan pembobotannya.

mahasiswa dalam memahami materi yang telah diberikan oleh dosen, khususnya ketika di pertengahan pembelajaran (UTS) dan di akhir pembelajaran (UAS).

Tujuan dari penelitian ini yaitu implementasi sistem temu kembali informasi untuk mencari kesesuaian dan kecocokan antara soal dengan dokumen Rencana Dosen diharapkan memiliki kemampuan yang memadai Pembelajaran Semester (RPS). Kesesuaian tersebut dalam mengembangkan dan menyusun soal ujian untuk dihasilkan dari perhitungan menggunakan metode mengukur hasil belajar mahasiswa [4]. Kemampuan Vector Space Model, dimana beberapa penelitian dosen dalam mengembangkan soal ujian dapat sebelumnya telah berhasil menerapkan metode tersebut mempengaruhi kualitas belajar mahasiswa. Jika dosen dalam pencarian kecocokan antar dokumen [11], [12], tidak mampu dalam membuat soal ujian yang baik, maka [13], [14].

mahasiswa mengalami kesulian dalam pemahaman yang tidak tergali sepenuhnya. Sehingga hal ini menghasilkan mutu lulusan menjadi rendah [5]. Salah satu cara untuk mengetahui kualitas soal ujian yang dibuat yaitu dengan melihat kaidah penulisan soal ujian dari segi materi pokok yang terdapat di dalam dokumen rencana pembelajaran. Maka dari itu, soal ujian yang disusun harus disesuaikan dengan materi pokok pada setiap capaian pembelajaran mata kuliah.

\section{Metode Penelitian}

Proses pencarian kemiripan dalam sistem temu kembali informasi ini diterapkan menggunakan sistem penyimpanan dokumen Rencana Pembelajaran Semester (RPS) yang berformat (.xlsx). Proses pada user memasukkan query butir soal ujian secara manual ke dalam sistem. Penelitian ini bertujuan untuk mengetahui kemiripan tertinggi setiap butir soal ujian dengan materi Solusi yang diberikan yaitu menerapkan konsep temu pokok yang ada pada dokumen RPS. Dokumen akan kembali informasi sebagai sistem/mesin pencarian dilakukan indexing yang berdasarkan pada semua isi kesesuaian antara soal ujian dengan dokumen rencana dokumen. Selanjutnya, akan dilakukan text-processing pembelajaran berdasarkan pada materi pokok. Sistem yang meliputi tokenizing, stopword removal, dan pencarian digunakan untuk menemukan informasi yang stemming. Proses pembobotan pada metode ini relevan dengan kebutuhan user secara otomatis [6]. menggunakan TF-IDF dan hasil yang diperoleh Teknik yang dapat digunakan untuk menyelesaikan digunakan untuk perhitungan menggunakan Vector permasalahan tersebut adalah information retrieval dan Space Model (VSM). Hasil akhir yang didapatkan text mining. Text mining adalah proses menggali adalah nilai kemiripan antara materi pokok pada informasi dimana user berinteraksi dengan beberapa dokumen RPS yang telah diurutkan dari yang paling dokumen menggunakan suatu tools analysis, yang tinggi nilainya berdasarkan query butir soal ujian yang merupakan komponen-komponen dalam penambangan dimasukkan. Kerangka aplikasi sistem pada penelitian data [7]. Salah satu penelitian tentang text mining ini ditunjukkan pada Gambar 1.

digunakan untuk pencari dan pencocokan dokumen teks 


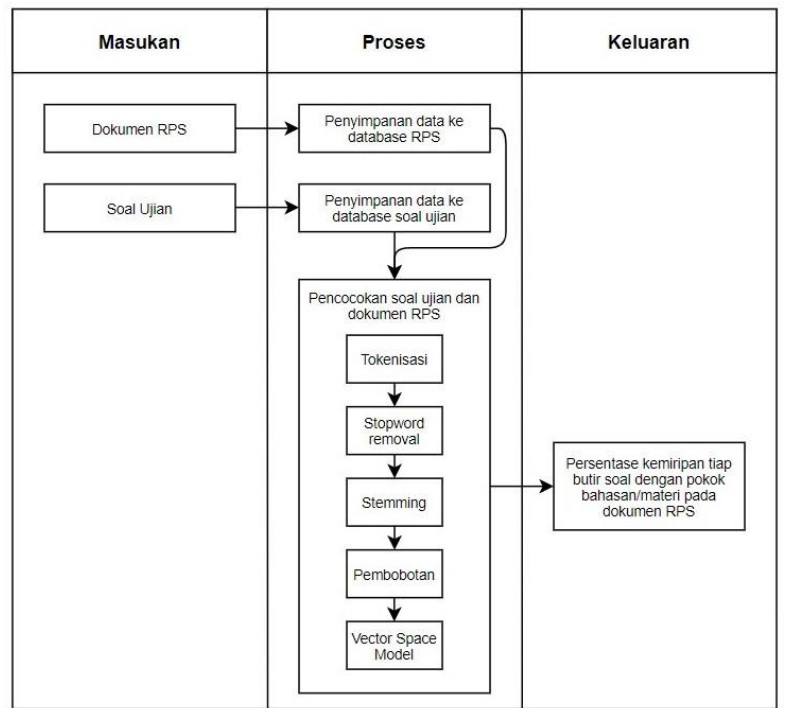

Gambar 1. Kerangka Aplikasi Sistem

\subsection{Pre-processing}

Tujuan dari dilakukannya tahap pre-processing pada text-mining adalah ketika dokumen atau teks banyak mengandung unsur yang tidak baku, terdapat imbuhan, simbol, angka dan sebagainya. Setiap teks akan dipecah dengan $N$ adalah jumlah dokumen dan $D F_{i}$ adalah menjadi struktur bagian kecil, biasanya menjadi suatu jumlah dokumen dimana kata (term) muncul di kata, yang akan memiliki makna yang sempit. Tahapan dalamnya. yang terdapat pada pre-processing yaitu:

\section{a) Tokenizing}

Tokenizing merupakan proses pemecahan sebuah dokumen menjadi unsur bagian terkecil yang disebut dengan token. Pemecahan ini dapat berupa pemecahan kalimat menjadi kata, simbol, frase dan entitas penting lainnya. Proses ini pada waktu yang bersamaan dilakukan juga penghapusan karakter tertentu, misalkan seperti simbol maupun tanda baca dan mengubah semua huruf menjadi huruf kecil (lowercase).

\section{b) Stopword Removal}

Kata-kata yang tidak memiliki arti dilakukan proses penghapusan kata untuk dijadikan sebagai kata kunci dalam pencarian dokumen. Kata-kata (stopword) yang diabaikan untuk kemudian dihapuskan, disimpan ke dalam stoplists. Tujuannya adalah untuk mengurangi jumlah kata pada dataset yang akan berpengaruh pada kecepatan dan performa kinerja sistem.

\section{c) Stemming}

Stemming merupakan proses pengubahan sebuah kata dengan $|q|$ adalah jarak query dan $W_{i q}$ adalah bobot menjadi kata dasarnya dengan cara menghilangkan query yang dihitung dari hasil pengindeksan dan semua imbuhan kata. Imbuhan kata tersebut meliputi pembobotan kata (term) dari query.

awalan (prefixes), sisipan (infixes), akhiran (suffixes), serta awalan dan akhiran (confixes) pada kata turunannya. Library yang digunakan untuk melakukan proses stemming pada penelitian ini adalah Sastrawi 1.0.1.

\subsection{Perhitungan Menggunakan Vector Space Model} dilakukan proses perhitungan kemiripan antar query dan dokumen menggunakan metode Vector Space Model. Proses menghitung kemiripan diperlukan suatu pembobotan terlebih dahulu. Term Frequency - Inverse Document Frequency (TF-IDF) merupakan faktor untuk menghitung bobot pada pengambilan suatu informasi. Data yang telah melalui tahap pre-processing memiliki bentuk numerik. TF-IDF digunakan untuk mengubah data yang berupa kata-kata menjadi numerik. Nilai TF diperoleh dari banyaknya kemunculan kata (term) pada sebuah dokumen. Nilai TF akan besar jika kata tersebut sering muncul dan akan kecil jika kata tersebut jarang muncul. Nilai IDF diperoleh dari banyaknya kata (term) yang dicari pada koleksi dokumen yang ada pada database.

Penelitian ini, nilai $T F_{i}$ dihitung menggunakan nilai frekuensi kemunculan setiap kata. Nilai $I D F_{i}$ dihitung menggunakan persamaan:
$I D F_{i}=\log$
dengan $N$
jumlah do
dalamnya.

Perhitungan TF-IDF menggunakan persamaan:

$W_{i j}=T F_{i j} \times \log _{10}\left(\frac{N}{1+D F_{i}}\right)$

dengan $W_{i j}$ adalah bobot dokumen, $T F_{i j}$ adalah frekuensi kemunculan kata $\left(T_{i}\right)$ pada dokumen $\left(D_{j}\right), N$ adalah jumlah dokumen dan $D F_{i}$ adalah jumlah dokumen dimana kata $\left(T_{i}\right)$ muncul di dalamnya.

Hasil dari persamaan (1) dan (2) akan dimasukkan ke dalam suatu matriks dengan cara mengkalikan nilai $T F_{i j}$ dan nilai $I D F_{i}$. Hasil perkalian tersebut kemudian akan dimasukkan ke dalam suatu dokumen baru. Dokumen ini akan diberikan index sesuai dengan kandidat kata kunci. Setiap kandidat kata kunci akan memiliki bobot, dimana bobot ini berasal dari perkalian antara vektor kata pada query $\left(W_{i q}\right)$ dengan vektor dokumen $\left(W_{i j}\right)$.

Perhitungan jarak pada query menggunakan persamaan:

$|q|=\sqrt{\sum_{i=1}^{t}\left(W_{i q}\right)^{2}}$

Sedangkan perhitungan jarak pada dokumen menggunakan persamaan:

$\left|d_{j}\right|=\sqrt{\sum_{i=1}^{t}\left(W_{i j}\right)^{2}}$
Setelah data melalui tahap pre-processing, akan 
dengan $\left|d_{j}\right|$ adalah jarak dokumen dan $W_{i j}$ adalah bobot a) Tokenizing

dokumen yang dihitung dari hasil pengindeksan dan pembobotan kata (term) dari kandidat kata kunci.

Hasil pada tahap ini adalah kalimat-kalimat pada materi pokok di dokumen RPS yang sudah terpecah menjadi

Perhitungan kemiripan antara query dan dokumen kata-kata, seperti terlihat pada Tabel 2. dilakukan dengan perkalian antara vektor query dan vektor kandidat kata kunci pada dokumen kemudian dibagi dengan perkalian antara nilai absolut jarak query dan jarak dokumen, menggunakan persamaan:

$\operatorname{Sim}\left(q, d_{j}\right)=\frac{q \times d_{j}}{|q| \times\left|d_{j}\right|}=\frac{\sum_{i=1}^{t} W_{i q} \times W_{i j}}{\sqrt{\sum_{i=1}^{t}\left(W_{i q}\right)^{2} \times \sum_{i=1}^{t}\left(W_{i j}\right)^{2}}}$

dengan $|q|$ adalah jarak query, $\left|d_{j}\right|$ adalah jarak dokumen, $W_{i q}$ adalah bobot query yang dihitung dari hasil pengindeksan dan pembobotan kata (term) dari query, dan $W_{i j}$ adalah bobot dokumen yang dihitung dari hasil pengindeksan dan pembobotan kata (term) dari kandidat kata kunci.

Nilai kemiripan yang paling tinggi antara query butir soal ujian dengan materi pokok pada dokumen RPS akan diberikan oleh sistem dalam bentuk persentase.

\section{Hasil dan Pembahasan}

\subsection{Pre-processing}

Sebelum melakukan pencarian kemiripan antara query soal ujian dengan dokumen RPS, terlebih dahulu dilakukan proses pembersihan pada data teks yang akan digunakan. Terdapat sebuah query yang diuji yaitu satu butir soal UTS mata kuliah Kalkulus yang berbunyi: "Hitunglah integral trigonometri dari fungsi berikut! $\int \sin ^{7} x d x$ ". Query tersebut kemudian dicari kemiripannya dengan data uji. Penelitian ini menggunakan data uji sebanyak 2 (dua) data materi pokok yang terdapat pada dokumen RPS mata kuliah Kalkulus, yang dapat dilihat pada Tabel 1.

Tabel 1. Data Uji Penelitian

\begin{tabular}{ccl}
\hline \multicolumn{3}{c}{ Dokumen RPS Mata Kuliah Kalkulus } \\
\hline Pokok & & \multicolumn{1}{c}{ Keterangan } \\
\hline & 1. & kontrak kuliah \\
& 2. & pengintegralan dengan substitusi \\
& 3. & integral trigonometri \\
& 4. & substitusi yang merasionalkan \\
& 5. & pengintegralan parsial \\
& 6. & pengintegralan fungsi rasional \\
& 1. & integral tak wajar \\
& 2. & bentuk tak tentu jenis 0/0 \\
& 3. & bentuk tak tentu yang lain \\
& 4. & integral tak wajar dengan batas \\
& & pengintegralan tak hingga \\
& 5. & integral tak wajar dengan fungsi integran \\
& & tak hingga di satu titik tertentu \\
\hline
\end{tabular}
Setiap data uji terlebih dahulu akan melalui tahapan pre- masing materi pokok pada sebuah dokumen RPS. processing yang terdiri dari tokenizing, stopword Delapan term yang terbentuk kemudian dilakukan removal, dan stemming untuk selanjutnya dilakukan proses pembobotan term menggunakan metode TF-IDF. proses pembobotan menggunakan TF-IDF serta perhitungan kemiripan menggunakan VSM.

Tabel 2. Hasil Tokenizing

\begin{tabular}{clll}
\hline \multicolumn{3}{c}{ Dokumen RPS Mata Kuliah Kalkulus } \\
\hline $\begin{array}{c}\text { Materi } \\
\text { Pokok }\left(\mathrm{D}_{\mathrm{i}}\right)\end{array}$ & \multicolumn{3}{c}{ Keterangan $($ Term $)$} \\
\hline & kontrak & integral & pengintegralan \\
kuliah & trigonometri & parsial \\
& pengintegralan & substitusi & pengintegralan \\
& dengan & yang & fungsi \\
& substitusi & merasionalkan & rasional \\
\hline & integral & yang & tak \\
& tak & lain & wajar \\
& wajar & integral & dengan \\
& bentuk & tak & fungsi \\
& tak & wajar & integran \\
& tentu & dengan & tak \\
& jenis & batas & hingga \\
& $0 / 0$ & pengintegralan & di \\
& bentuk & tak & satu \\
& tak & hingga & titik \\
& tentu & integral & tertentu \\
\hline
\end{tabular}

\section{b) Stopword Removal}

Pada tahap ini yaitu menghapuskan kata-kata yang tidak memiliki arti atau tidak relevan, seperti terlihat pada Tabel 3.

Tabel 3. Hasil Stopword Removal

\begin{tabular}{clll}
\hline \multicolumn{3}{l}{ Dokumen RPS Mata Kuliah Kalkulus } \\
\hline $\begin{array}{c}\text { Materi } \\
\left(\mathrm{D}_{\mathrm{i}}\right)\end{array}$ & & Keterangan (Term) & \\
\hline & kontrak & trigonometri & pengintegralan \\
& kuliah & substitusi & fungsi \\
1 & pengintegralan & merasionalkan & rasional \\
& substitusi & pengintegralan & \\
& integral & parsial & \\
\hline & integral & lain & fungsi \\
& tak & integral & integran \\
& wajar & tak & tak \\
& bentuk & wajar & hingga \\
& tak & batas & satu \\
& tentu & pengintegralan & titik \\
& jenis & tak & tertentu \\
& bentuk & hingga & wajar \\
& tak & integral & \\
& tentu & tak & \\
\hline
\end{tabular}

\section{c) Stemming}

Hasil pada tahap ini adalah kata-kata yang sudah tidak memiliki imbuhan awal atau akhir serta menjadi katakata dasar, seperti ditunjukkan pada Tabel 4.

Tabel 4 terlihat bahwa terdapat 8 (delapan) term yang dihasilkan oleh proses pre-processing dari masing-

(n) 
Tabel 4. Hasil Stemming

\begin{tabular}{cll}
\hline \multicolumn{3}{c}{ Dokumen RPS Mata Kuliah Kalkulus } \\
\hline $\begin{array}{c}\text { Materi } \\
\text { Pokok } \\
\left(\mathrm{D}_{\mathrm{i}}\right)\end{array}$ & \multicolumn{2}{c}{ Keterangan $($ Term $)$} \\
\hline & kontrak & trigonometri \\
& kuliah & rasional \\
1 & integral & parsial \\
& substitusi & fungsi \\
\hline & integral & batas \\
& wajar & fungsi \\
& bentuk & integran \\
& jenitik \\
\hline
\end{tabular}

\subsection{Pembobotan Menggunakan TF-IDF}

Penelitian ini, dilakukan pencarian kemiripan 1 (satu) butir soal UTS mata kuliah Kalkulus yang berbunyi: "Hitunglah integral trigonometri dari fungsi berikut! $\int \sin ^{7} x d x$ " dengan data 2 (dua) materi pokok pada sebuah dokumen RPS. Hasil dari penggunaan persamaan (1) terlihat pada Tabel 5.

Tabel 5. Hasil Perhitungan TF-IDF

\begin{tabular}{|c|c|c|c|c|c|}
\hline \multirow{2}{*}{$\begin{array}{c}\text { Materi } \\
\text { Pokok }\left(D_{i}\right)\end{array}$} & \multirow{2}{*}{ Term } & \multicolumn{2}{|c|}{$\mathrm{TF}_{\mathrm{i}}$} & \multirow{2}{*}{ DF } & \multirow{2}{*}{$\mathrm{IDF}_{\mathrm{i}}$} \\
\hline & & RPS & Soal & & \\
\hline \multirow{11}{*}{ 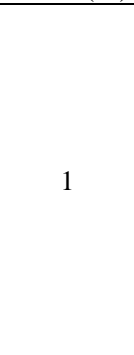 } & kontrak & 1 & 0 & 1 & 0,4771 \\
\hline & kuliah & 1 & 0 & 1 & 0,4771 \\
\hline & integral & 4 & 1 & 2 & 0,1761 \\
\hline & substitusi & 2 & 0 & 1 & 0,4771 \\
\hline & trigonometri & 1 & 1 & 2 & 0,1761 \\
\hline & rasional & 2 & 0 & 1 & 0,4771 \\
\hline & parsial & 1 & 0 & 1 & 0,4771 \\
\hline & fungsi & 1 & 1 & 2 & 0,1761 \\
\hline & hitung & 0 & 1 & 1 & 0,4771 \\
\hline & $\sin$ & 0 & 1 & 1 & 0,4771 \\
\hline & $\mathrm{dx}$ & 0 & 1 & 1 & 0,4771 \\
\hline \multirow{12}{*}{2} & integral & 4 & 1 & 2 & 0,1761 \\
\hline & wajar & 3 & 0 & 1 & 0,4771 \\
\hline & bentuk & 2 & 0 & 1 & 0,4771 \\
\hline & jenis & 1 & 0 & 1 & 0,4771 \\
\hline & batas & 1 & 0 & 1 & 0,4771 \\
\hline & fungsi & 1 & 1 & 2 & 0,1761 \\
\hline & integran & 1 & 0 & 1 & 0,4771 \\
\hline & titik & 1 & 0 & 1 & 0,4771 \\
\hline & hitung & 0 & 1 & 1 & 0,4771 \\
\hline & trigonometri & 0 & 1 & 1 & 0,4771 \\
\hline & $\sin$ & 0 & 1 & 1 & 0,4771 \\
\hline & $d x$ & 0 & 1 & 1 & 0,4771 \\
\hline
\end{tabular}

Tabel 5 terlihat bahwa kolom Term merupakan indeks kata kunci yang terpilih pada setiap dokumen serta kolom $T F_{i}$ merupakan jumlah term yang muncul pada setiap query dan dokumen. Kolom DF pada term "kontrak" diperoleh dari frekuensi dokumen RPS yang mengandung term "kontrak" yaitu sebanyak 1 (satu) dokumen. Kolom $I D F_{i}$ merupakan hasil dari perhitungan menggunakan persamaan (1).

Nilai TF dan IDF didapatkan kemudian dilanjutkan dengan perhitungan bobot untuk setiap term. Kolom $W_{i j}$ yang terlihat pada Tabel 6 merupakan nilai bobot dari setiap term, yang dapat dipandang sebagai matriks.

Tabel 6 terlihat bahwa setiap term memiliki nilai bobot yang diperoleh dari jumlah term pada setiap dokumen dikalikan dengan nilai IDF. Term "kontrak" pada dokumen RPS memiliki nilai bobot sebesar 0,143627809 yang diperoleh dari perkalian antara nilai $T F$ dengan $I D F$-nya menggunakan persamaan (2).

Tabel 6. Hasil Perhitungan Bobot

\begin{tabular}{|c|c|c|c|}
\hline \multirow{2}{*}{$\begin{array}{c}\text { Materi } \\
\text { Pokok } \\
\left(D_{i}\right) \\
\end{array}$} & \multirow[b]{2}{*}{ Term } & \multicolumn{2}{|c|}{$W_{i j}$} \\
\hline & & RPS & Soal \\
\hline \multirow{11}{*}{1} & kontrak & 0,143627809 & 0 \\
\hline & kuliah & 0,143627809 & 0 \\
\hline & integral & 0,123082508 & 0,053008751 \\
\hline & substitusi & 0,227644692 & 0 \\
\hline & trigonometri & 0,053008751 & 0,053008751 \\
\hline & rasional & 0,227644692 & 0 \\
\hline & parsial & 0,143627809 & 0 \\
\hline & fungsi & 0,053008751 & 0,053008751 \\
\hline & hitung & 0 & 0,143627809 \\
\hline & $\sin$ & 0 & 0,143627809 \\
\hline & $\mathrm{dx}$ & 0 & 0,143627809 \\
\hline \multirow{12}{*}{2} & integral & 0,123082508 & 0,053008751 \\
\hline & wajar & 0,287255618 & 0 \\
\hline & bentuk & 0,227644692 & 0 \\
\hline & jenis & 0,143627809 & 0 \\
\hline & batas & 0,143627809 & 0 \\
\hline & fungsi & 0,053008751 & 0,053008751 \\
\hline & integran & 0,143627809 & 0 \\
\hline & titik & 0,143627809 & 0 \\
\hline & hitung & 0 & 0,143627809 \\
\hline & trigonometri & 0 & 0,143627809 \\
\hline & $\sin$ & 0 & 0,143627809 \\
\hline & $\mathrm{dx}$ & 0 & 0,143627809 \\
\hline
\end{tabular}

Nilai bobot dari masing-masing term, dilanjutkan dengan perhitungan menggunakan Vector Space Model. Nilai bobot tersebut digunakan sebagai titik koordinat pada ruang vektor yang merepresentasikan setiap query dan dokumen sebagai sebuah vektor. Hasil perhitungan jarak antar query dan dokumen dapat dilihat pada Tabel 7.

Tabel 7. Hasil Perhitungan Jarak

\begin{tabular}{|c|c|c|c|}
\hline \multirow{2}{*}{$\begin{array}{c}\text { Materi } \\
\text { Pokok } \\
\left(D_{i}\right)\end{array}$} & \multirow[b]{2}{*}{ Term } & \multicolumn{2}{|c|}{ Nilai Jarak } \\
\hline & & RPS & Soal \\
\hline \multirow{11}{*}{1} & kontrak & 0,020628948 & 0 \\
\hline & kuliah & 0,020628948 & 0 \\
\hline & integral & 0,015149304 & 0,002809928 \\
\hline & substitusi & 0,051822106 & 0 \\
\hline & trigonometri & 0,002809928 & 0,002809928 \\
\hline & rasional & 0,051822106 & 0 \\
\hline & parsial & 0,020628948 & 0 \\
\hline & fungsi & 0,002809928 & 0,002809928 \\
\hline & hitung & 0 & 0,020628948 \\
\hline & $\sin$ & 0 & 0,020628948 \\
\hline & $\mathrm{dx}$ & 0 & 0,020628948 \\
\hline & Total & 0,431625084 & 0,265172822 \\
\hline \multirow{13}{*}{2} & integral & 0,123082508 & 0,053008751 \\
\hline & wajar & 0,287255618 & 0 \\
\hline & bentuk & 0,227644692 & 0 \\
\hline & jenis & 0,143627809 & 0 \\
\hline & batas & 0,143627809 & 0 \\
\hline & fungsi & 0,053008751 & 0,053008751 \\
\hline & integran & 0,143627809 & 0 \\
\hline & titik & 0,143627809 & 0 \\
\hline & hitung & 0 & 0,143627809 \\
\hline & trigonometri & 0 & 0,143627809 \\
\hline & $\sin$ & 0 & 0,143627809 \\
\hline & $\mathrm{dx}$ & 0 & 0,143627809 \\
\hline & Total & 0,484574987 & 0,296876482 \\
\hline
\end{tabular}


Tabel 7 terlihat bahwa masing-masing query dan Ucapan Terima Kasih dokumen RPS memiliki nilai jarak "Total". Nilai tersebut didapatkan dari perhitungan menggunakan persamaan (3) untuk query butir soal ujian dan persamaan (4) untuk materi pokok pada dokumen RPS, dengan rincian sebagai berikut:

Materi pokok 1: $\quad|q|=0,265172822$

$$
\left|D_{1}\right|=0,431625084
$$

Materi pokok 2: $\quad|q|=0,296876482$

$$
\left|D_{2}\right|=0,484574987
$$

Tim penulis mengucapkan terima kasih kepada Direktorat Riset dan Pengabdian Masyarakat, Direktorat Jenderal Penguatan Riset dan Pengembangan, Kementerian Riset, Teknologi dan Pendidikan Tinggi (KEMENRISTEKDIKTI) yang telah mendanai penelitian ini melalui skema program Penelitian Dasar Pemula tahun 2020.

\section{Daftar Rujukan}

[1] Sitepu, B. P. and Lestari, I., 2018. Pelaksanaan Rencana Pembelajaran Semester dalam Proses Pembelajaran di Perguruan Tinggi. PERSPEKTIF Ilmu Pendidikan, 32 (1), pp.43-51.

Masing-masing didapatkan nilai jarak pada setiap query dan dokumen serta nilai jarak absolutnya, selanjutnya akan dicari nilai kemiripan query butir soal ujian dengan kata kunci pada materi pokok dokumen RPS menggunakan persamaan (5). Proses selanjutnya, perangkingan sesuai dengan nilai yang terbesar ke nilai yang terkecil dalam bentuk persentase.

Tabel 8. Hasil Perhitungan Kemiripan

\begin{tabular}{ccc}
\hline No. Urut & Materi Pokok & Persentase \\
\hline 1 & $\mathrm{D}_{1}$ & $10,6 \%$ \\
2 & $\mathrm{D}_{2}$ & $6,5 \%$ \\
\hline
\end{tabular}

Sundari, D. and Pangaribuan, T. R., 2017. Analisis Soal Semester Ganjil Mata Pelajaran Bahasa Indonesia Kelas VII SMP Negeri 2 Percut Sei Tuan Tahun Pembelajaran 2016/2017. Asas: Jurnal Sastra, 6 (2), pp.1-10.

[3] Sudjana, N., 2005. Penilaian Hasil Proses Belajar Mengajar. Bandung: PT. Remaja Rosdakarya.

[4] Munadi, S., 2011. Analisis Validasi Kualitas Soal Tes Hasil Belajar pada Pelaksanaan Program Pembelajaran. Jurnal Cakrawala Pendidikan, 1 (1), pp.145-159.

[5] Taib, E. N., 2014. Analisis Kualitas Aspek Materi Butir Soal Buatan Dosen. Jurnal Biotik, 2 (2), pp.116-121.

[6] Sugara, B., Dody and Donny, 2019. Sistem Temu Kembali Informasi pada Gejala Autisme dengan Metode Vector Space Model. Jurnal RESTI (Rekayasa Sistem dan Teknologi Informasi), 3 (2), pp.257-264.

Tabel 8 menunjukkan hasil perhitungan kemiripan antara query soal ujian yang berbunyi "Hitunglah integral trigonometri dari fungsi berikut! $\int \sin ^{7} x d x$ " dengan 2 (dua) materi pokok pada dokumen RPS yang diuji. Hasil tingkat kemiripan antara materi pokok pertama $\left(\mathrm{D}_{1}\right)$ dalam dokumen RPS dengan query butir soal ujian yang diuji yaitu sebesar 10,6\%. Materi pokok pertama $\left(\mathrm{D}_{1}\right)$ memiliki lebih banyak kata (term) yang relevan atau mirip dengan kata kunci yang terdapat pada query soal ujian, jika dibandingkan dengan materi pokok kedua $\left(\mathrm{D}_{2}\right)$.

\section{Kesimpulan}

Hasil penelitian menunjukkan bahwa metode Vector Space Model dapat diimplementasikan sebagai sistem pencarian dalam menemukan kesesuaian antara soal ujian dengan dokumen rencana pembelajaran. Pencarian kesesuaian tersebut diurutkan berdasarkan nilai kemiripan hasil perhitungannya, dari nilai terbesar ke nilai terkecil dalam bentuk persentase. Nilai yang dihasilkan oleh sistem memiliki arti bahwa query butir soal ujian tersebut telah memiliki kesesuaian dengan suatu materi pokok pada dokumen rencana pembelajaran.

Wisnu, D. and Hetami, A., 2015. Perancangan Information Retrieval (IR) untuk Pencarian Ide Pokok Teks Artikel Berbahasa Inggris dengan Pembobotan Vector Space Model. Jurnal Ilmiah Teknologi dan Informasi, 9 (9).

[8] Karyono, G. and Utomo, F. S., 2012. Temu Balik Informasi pada Dokumen Teks Berbahasa Indonesia dengan Metode Vector Space Model. In: Seminar Nasional Teknologi Informasi \& Komunikasi Terapan 2012 (SEMANTIK 2012), Semarang. Siregar, R. R. A., Sinaga, F., A., and Arianto, R., 2017. Aplikasi Penentuan Dosen Penguji Skripsi Menggunakan Metode TFIDF dan Vector Space Model. Computatio: Journal of Computer Science and Information Systems, 1 (2), pp.171-186.

[10] Fauzi, A. and Ginabila, 2018. Information Retrieval System pada File Pencarian Dokumen Tesis Berbasis Text Menggunakan Metode Vector Space Model. Jurnal PILAR Nusa Mandiri, 14 (2), pp.41-46.

111] Leman, D. and Andesa, K., 2017. Implementasi Vector Space Model Untuk Meningkatkan Kualitas Pada Sistem Pencarian Buku Perpustakaan. In: Seminar Nasional Informatika 2015 (SNIf), 1 (1), pp.8-15.

[12] Gawande, P. S. and Suryawanshi, A., 2015. Improving Web Page Classification by Vector Space Model. International Journal of Innovative Research in Computer and Communication Engineering, 3 (2), pp.1252-1257.

[13] Suprianto, Sunardi, and Fadlil, A., 2019. Aplikasi Sistem Temu Kembali Angket Mahasiswa Menggunakan Metode Generealized Vector Space Model. Jurnal Teknologi Informasi dan Ilmu Komputer (JTIIK), 6 (1), pp.33-40.

[14] Jovita, Linda, Hartawan A. and Suhartono, D., 2015. Using Vector Space Model in Question Answering System. Procedia Computer Science, 59 (2015), pp.305-311. 